\title{
A New Stegolophodon (Proboscidea, Mammalia) from the Irrawaddy Formation of Myanmar
}

\author{
Chit Sein \\ Department of Geology, West Yangon University, Yangon, Myanmar \\ Email: chitsein@moe.edu.mm
}

How to cite this paper: Sein, C. (2020) A New Stegolophodon (Proboscidea, Mammalia) from the Irrawaddy Formation of Myanmar. Open Journal of Geology, 10, 863-873. https://doi.org/10.4236/ojg.2020.108039

Received: June 23, 2020

Accepted: August 8, 2020

Published: August 11, 2020

Copyright $\odot 2020$ by author(s) and Scientific Research Publishing Inc. This work is licensed under the Creative Commons Attribution International License (CC BY 4.0).

http://creativecommons.org/licenses/by/4.0/

\begin{abstract}
The new fossil teeth of Stegolophodon (Proboscidea, Mammalia) were discovered from the terrestrial sediments of the Irrawaddy Formation, in Kyauksaungsan and Tebingan areas, Magway Region, central Myanmar. A new Stegolophodon species is established in this paper. Stegolophodon iravaticus shares the characters of the advanced Stegolophodon and the primitive Stegodon. The $\mathrm{M}_{3}$ of $S$. iravaticus is related to that of the molar of Sand Pit in Tha Chang, Thailand and that of from Dhedari, Pakistan which is included in the Stegolophodon group 6 of Saegusa et al. (2005).
\end{abstract}

\section{Keywords}

Stegolophodon iravaticus, Irrawaddy Formation, Magway Region, Myanmar

\section{Introduction}

Proboscideans have been known to occur in the Irrawaddy Formation of Myanmar since the beginning of the nineteenth century [1] described two new stegodontids, Stegolophodon latidens and Stegodon elephantoides which were found in the sediments of the Irrawaddy Formation near Yenangyaung, central Myanmar. Osborn (1942) [2] established a new Stegodon subspecies Stegodon insignis birmanicus which was collected from Mingun, opposite of Mandalay, central Myanmar. Colbert $(1938,1943)$ [3] [4] reported to the previous species of stegodontids from the various places of Myanmar. The species of the Stegodontidae of Irrawaddy Formation, Myanmar are very few and limited the publication for the long vertebrate fossils records, because of the fragmentary and paucity of the specimens and it has very few vertebrate paleontologists who interest in fossil proboscidea in Myanmar. Recently many fossil specimens of stegodontids and other mammals were collected from the Kyauksaungsan, Sin- 
baungwe Township and Tebingan, Migyaungye Twonship, Magway Region, central Myanmar [5] (Figure 1). The description of new stegodontids has not been recognized until now in Myanmar for long period although the new specimens were discovered. The present paper is intended to describe a new species of Stegolophodon (Mammalia, Proboscidea, Stegodontidae) among the newly discovered proboscidean materials from these localities. Additionally the geological setting and stratigraphic description of the Irrawaddy Formation around the fossil localities is provided.

\section{Abbreviation}

YUDG-Sbw, University of Yangon, Department of Geology-Sinbaungwe (name of the Township, Magway Region, central Myanmar); YUDG-Mge, University of Yangon, Department of Geology-Migyaungye (name of the Township, Magway Region, central Myanmar); CCV, Private Collection of Dr. Chavalit Vidthayanon, Bangkok; IVPP, Institute of Vertebrate Paleontology; BSM = Bayerische Staatssammlung für Paläontologie und historische Geologie, München.

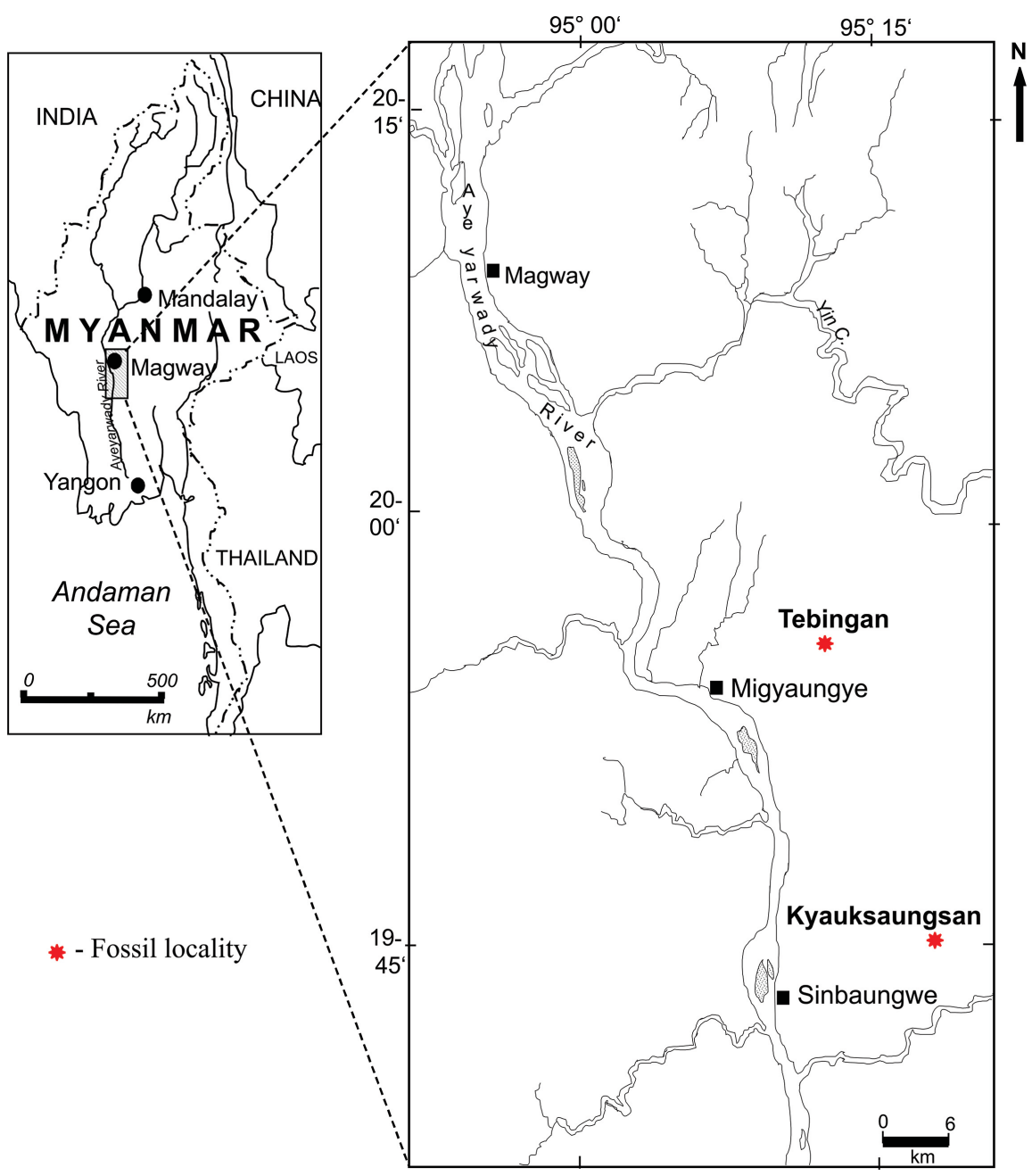

Figure 1. Map of the fossil localities (Source: Chit Sein, 2006) [6]. 


\section{Geological Setting and Stratigraphy}

The fossil localities of the present area are situated in the southern part of the Central Sub-basin of the Inner-Burman Tertiary Basin which is filled Paleogene and Neogene sediments [7]. The regional geological map of the present fossil localities is shown in Figure 2.

The Ayeyarwady (formerly Irrawaddy) River is flowing through the basin from North to South. On both sides of the Ayeyarwady River the Irrawaddy Formation is widely distributed. This formation consists mainly of light grey to yellowish brown, medium to thick bedded, coarse-grained, gritty, and loosely

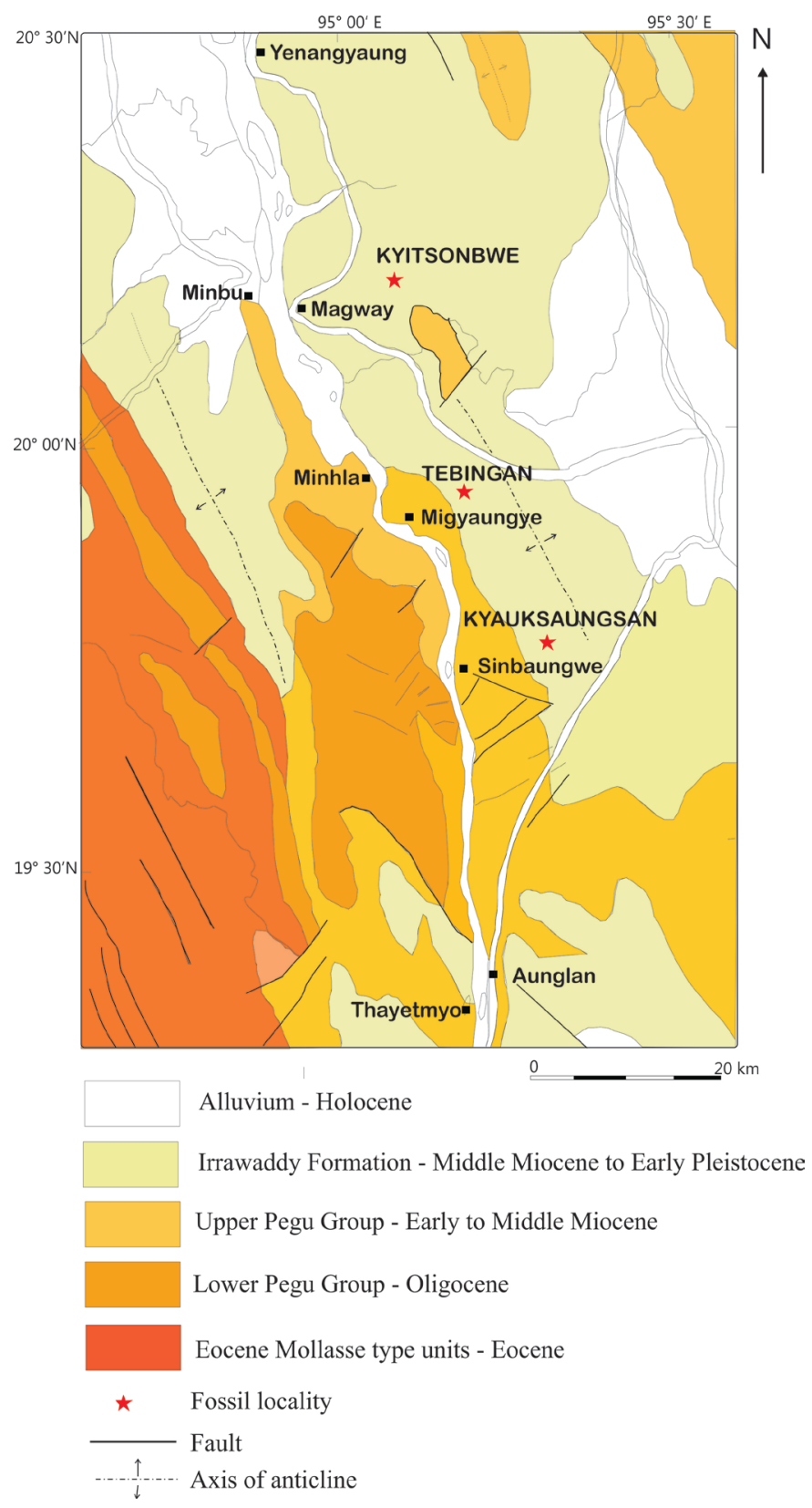

Figure 2. Regional geological map of the fossil localities (after Geological Map of Burma; 1: 1,000,000 scale, 1977). 
consolidated sandstones with intercalated siltstones and light grey colored claystone or mudstones. The most of the vertebrate fossils are found in occasionally occurring pebbly sandstones. Specimens of fossil wood and sandstone concretions are abundant.

The fossils studied here were collected from the right side of the Ayeyarwady River, in the south of Kyauksaungsan Village, about $11 \mathrm{~km}$ east of Sinbaungwe Township, and east of Tebingan Village, about $13 \mathrm{~km}$ northeast of Migyaungye Township, Magway Region from sediments of the Irrawaddy Formation. The columnar sections of the fossil localities are shown in Figure 3.

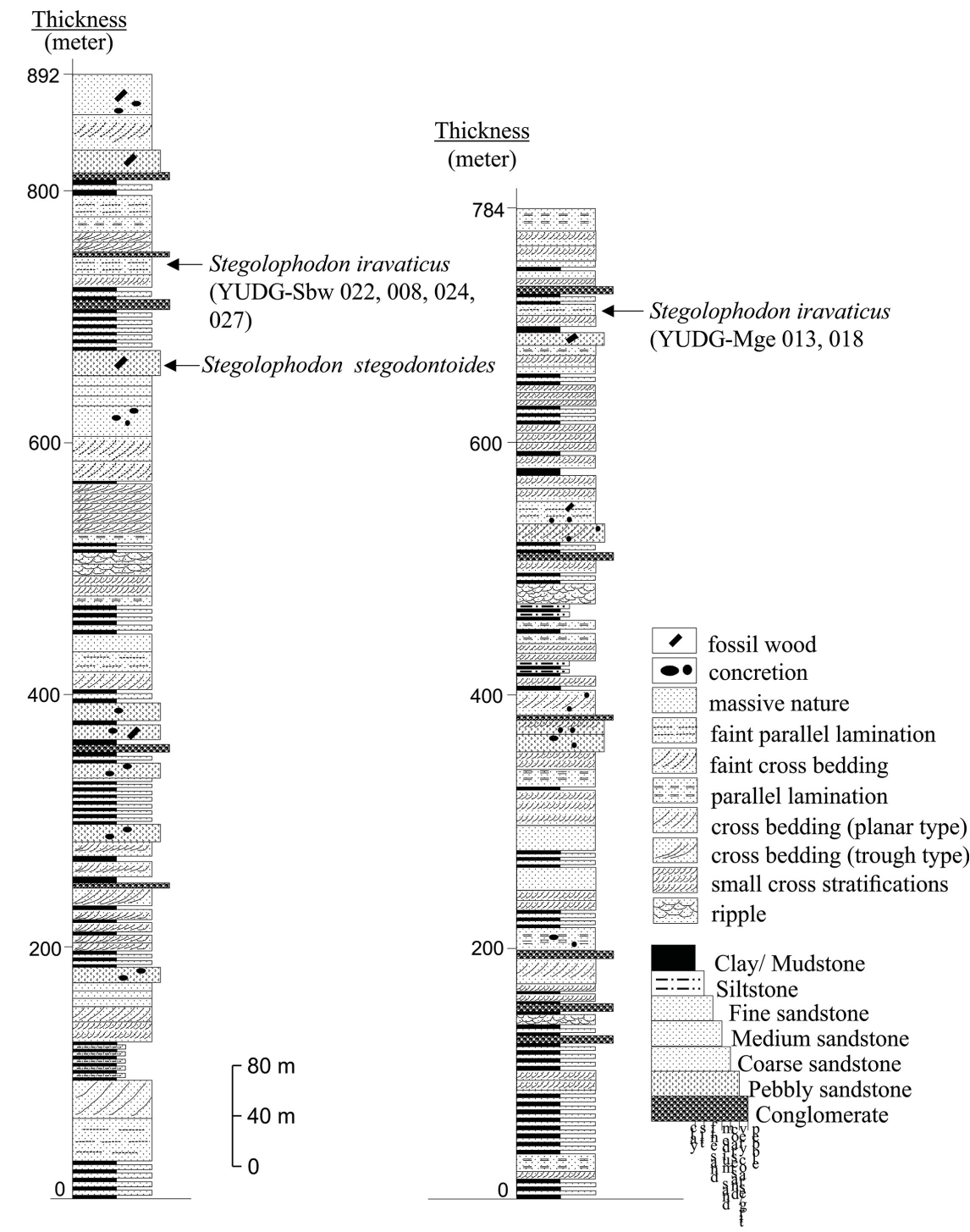

$19^{\circ} 41^{\prime} 23.3^{\prime \prime} \mathrm{N} ; 95^{\circ} 17^{\prime} 50.0^{\prime \prime} \mathrm{E}$

(a) $19^{\circ} 57^{\prime} 07.6 " \mathrm{~N} ; 95^{\circ} 08^{\prime} 15.2$ " $\mathrm{E}$

(b)

Figure 3. Columnar sections of the Irrawaddy Formation at the fossil localities Kyauksaungsan and Tebingan localities with indication of the strata which yielded stegodontid fossils. (a) section of Kyauksaungsan locality, Sinbaungwe Township; (b) section of Tebingan locality, Migyaungwe Township. 
The alternations of thin bedded sandstone and mudstone are mostly encountered in the lower part of the sections. Small scale cross stratifications occur in the sandstones and most of the mudstones are mottled which is intercalated with red conglomerates. The fossils mammalian are rare or absent in the lower part (up to $300 \mathrm{~m}$ ).

The thick bedded sandstones with large cross beddings are present in the middle part of the sections ( 300 to $700 \mathrm{~m}$ ). Sometimes pebbly sandstones and reddish brown conglomerates found in this part. The intercalations of thin-bedded sandstone layers alternating with very thin mudstone layers are abundant. Small scale cross stratifications and ripples are noted in the sandstone beds. The specimens of suid, Tetraconodon sp. cf. T. magnus, Propotamochoerus "hysudricus", and a mandibular fragment of carnivore were found in the middle part. Fossil wood is rare.

The fossil teeth of stegodontids were common in the upper part of the sections in both localities. In this part ( $\sim 700 \mathrm{~m}$ and above) the sandstones are less coherent than those in the lower part described above. Very thin-bedded clay layers gradually decrease towards the top of this portion. The newly described specimens here, Stegolophodon iravaticus sp. nov. were recovered from the coarse-grained, thick bedded parallel laminated sandstones beds in both localities. The pebbly sandstones are occasionally found in this part. The dentitions of Stegolophodon stegodontoides were collected from one of the pebbly sandstone beds below a few meters of the Stegolophodon irvaticus position. Specimens of fossil wood are abundant. Conglomerate beds are often found. Hollow hematitic or limonitic iron concretions are abundant.

\section{Systematic Paleontology}

I follow the dental terminology used by [8] and some additional descriptive terminologies used by [9] and [10]. The classification of the Proboscidea is used by [11]. The dental measurements of the new Stegolophodon specimens are shown in Table 1.

Family Stegodontidae Osborn, 1918

Genus Stegolophodon Schlesinger, 1917

Type species Mastodon latidens Clift, 1828

Stegolophodon iravaticus sp. nov.

Figure 4

Holotype-Partial mandible with right $\mathrm{M}_{2-3}$ (YUDG-Sbw 022); partial mandible and incomplete molar of left $\mathrm{M}_{3}$ (YUDG-Sbw 008).

Referred materials - Partial of left $\mathrm{M}_{3}$ (YUDG-Sbw 024); distal half of right $\mathrm{M}_{3}$ (YUDG-Sbw 027); distal portion of left $\mathrm{M}_{3}$ (YUDG-Mge 013); and distal portion of right $\mathrm{M}_{3}$ (YUGD-Mge 018).

Type locality-Kyauksaungsan: Southeast of Kyauksaungsan Village (19 44'24.8”N:95 17’34.2”E), Sinbaungwe Township; Tebingan: West of Tebingan Village (1957'51.1”N; 9508’37.8”E), Migyaungye Township, Magway Re- 
gion, central Myanmar.

Stratum-Upper part of Irrawaddy Formation.

Repository-Stored in the Geological Museum of the University of Yangon, Yangon, Myanmar.

Diagnosis - The lophid formula $=\mathrm{x} 7 \mathrm{x}$ in $\mathrm{M}_{3}$; extreme brachyodonty; four conelets in the main lophids of the molar; the mesoconelets are as large as the principal cones; the anterior and posterior pretrite central conules are present in the mesial two lophids; the central conules are reduced or absent in the distal lophids; weak in distal displacement of pretrite main cone, distinct median sulcus in all lophids, and elongated distally.

Etymology-Named after the stratigraphic position (Irrawaddy Formation) where the specimens was discovered.

Description-All of the $\mathrm{M}_{3}$ s of the described specimens here are partially preserved except for the specimen (YUDG-Sbw 022) (Figure 4(a)) which preserved completed right $\mathrm{M}_{3}$, and partial $\mathrm{M}_{2}$. The mandibles (YUDG-Sbw 022 \& 008) (Figure 4(a) \& Figure 4(b)) are massive and deep. The jaws of both teeth are long and broad in the distal part but narrow mesially. The symphysis is short and reduced but partially damaged. Ascending ramus is broken at the upper part.

The morphology and the lophid number of $\mathrm{M}_{2}$ in (YUDG-Sbw 022) are unknown due to the damage. The last molars (YUDG-Sbw 022, 008, 024) (Figure 4(a), Figure 4(b) \& Figure 4(d)) are slightly curved externally along the axis of the tooth on occlusal view. They are bunodonty and brachyodonty, and elongated distally. Seven lophids are recognized on complete and partially complete $M_{3}$ s (YUDG-Sbw 022 and 008). On each lophid exhibits four to five conelets. The conelets are rounded and the mesoconelets are enlarged as the same size of

Table 1. Measurements ( $\mathrm{mm})$ of the molars of Stegolophodon iravaticus sp. nov. discovered in Kyauksaungsan and Tebingan, from the Irrawaddy Formation of central Myanmar, L: length, max. W: maximal width, max. H: maximal height, I: width index $(100 \mathrm{~W} / \mathrm{L}),+$ : estimated measurement for incomplete tooth. The number of conelets and loph(id)s are indicated to the characters of advanced Stegolophodon and the primitive Stegodon.

\begin{tabular}{|c|c|c|c|c|c|c|c|c|c|c|}
\hline \multicolumn{11}{|c|}{ Measurements in $\mathrm{mm}$} \\
\hline Specimen No. & Material & Length & $\begin{array}{l}\text { Max. } \\
\text { Width }\end{array}$ & $\begin{array}{l}\text { Max. } \\
\text { Height }\end{array}$ & $\mathrm{I}$ & $\mathrm{HI}$ & $\begin{array}{c}\text { Enamel } \\
\text { thickness }\end{array}$ & $\begin{array}{c}\text { No. of } \\
\text { loph(id)s }\end{array}$ & $\begin{array}{l}\text { Loph(id)s } \\
\text { per } 100 \mathrm{~mm}\end{array}$ & $\begin{array}{c}\text { No. of } \\
\text { Cone-lets }\end{array}$ \\
\hline YUDG-Sbw 008 & left $\mathrm{M}_{3}$ & $253.85+$ & 95.40 & 36.22 & - & 38 & 5.92 & $61 / 2+$ & 3 & $4-6$ \\
\hline YUDG-Sbw 024 & left $\mathrm{M}_{3}$ & $167.3+$ & 81.45 & 40.18 & - & 49.3 & 5.65 & 5 & 3 & 4 \\
\hline YUDG-Sbw 027 & right $M_{3}$ & $126.6+$ & 85.62 & 53.41 & - & 62.4 & 5.84 & $4 \frac{1}{2}+$ & 4 & 4 \\
\hline YUDG-Mge 013 & left $\mathrm{M}_{3}$ & $114.27+$ & 79.09 & 44.66 & - & 56.5 & 6.80 & $3+$ & 3 & 4 \\
\hline
\end{tabular}

+ estimated measurement for incomplete tooth; - not measurable. 


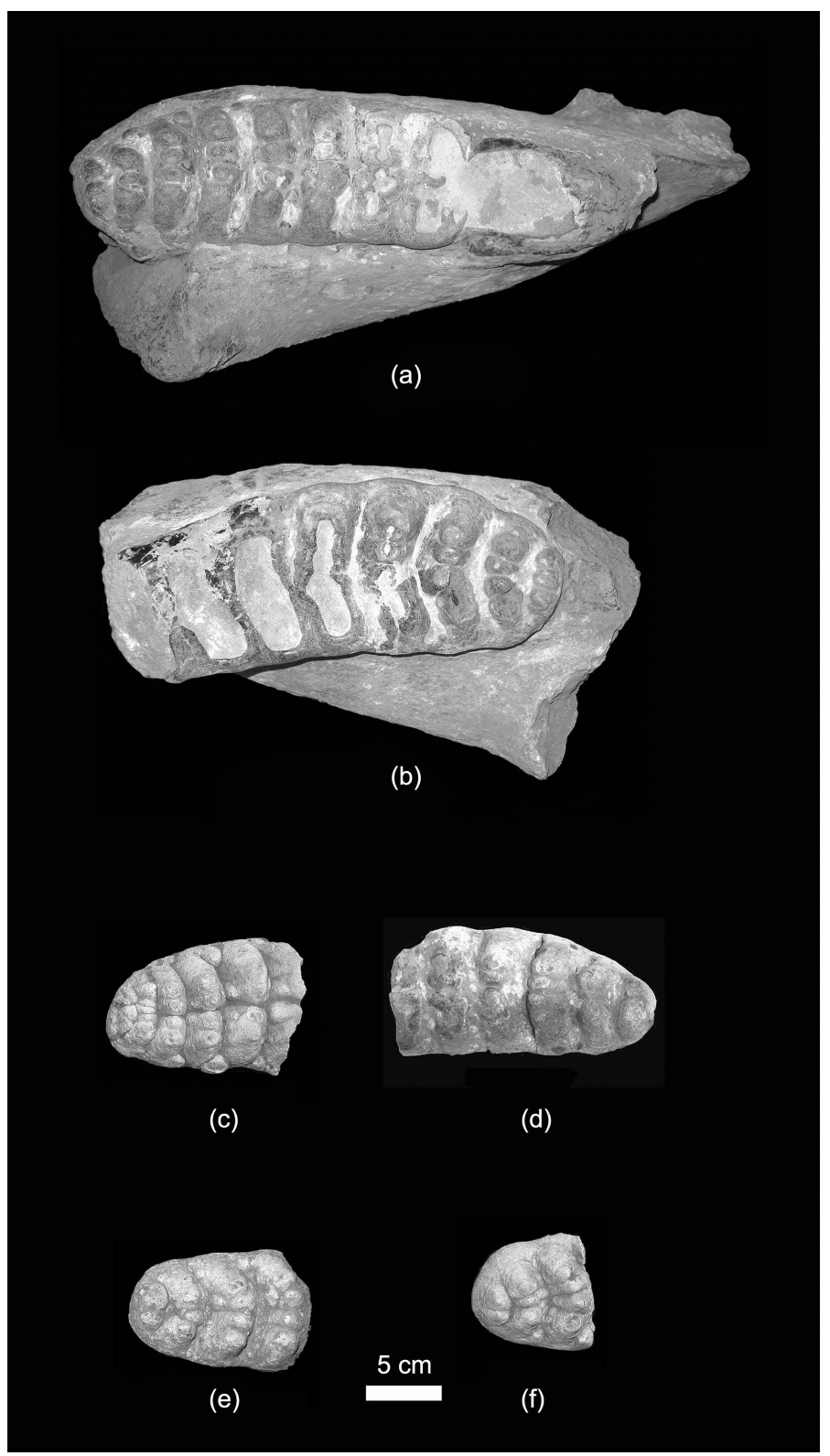

Figure 4. The teeth of Stegolophodon iravaticus sp. nov. from the localities of Kyauksaungsan and Tebingan of Irrawaddy Formation in Myanmar. (a) Partial mandible with right $\mathrm{M}_{2-3}$ (YUDG-Sbw 022); (b) partial mandible and incomplete molar of left $\mathrm{M}_{3}$ (YUDG-Sbw 008); (c) distal half of right $M_{3}$ (YUDG-Sbw 027); (d) Partial of left $M_{3}$ (YUDG-Sbw 024); (e) distal portion of left $\mathrm{M}_{3}$ (YUDG-Mge 013); (f) distal portion of right $\mathrm{M}_{3}$ (YUGD-Mge 018). All figures are occlusal view.

principal cones. The anterior and posterior central conules are developed only in the mesial two lophids in (YUDG-Sbw 022), however the fusion of the central conules and respective mesoconelet result as a big cusp. The central conules are reduced or absent in the distal lophids. The lophids are regular and transversely arranged, however the slightly distal displacement of the pretrite main cone is noted in the distal lophids of (YUDG-Sbw 008; YUDG-Mge 013 \& 018) (Figure 4(b), Figure 4(e), Figure 4(f)), but weaker than in Stegolophodon stegodon- 
toides. The apice of the lophids are occasionally straight, but the bases of the all lophids are convex-convex type. The medial sulcus is distinct in all lophids of all specimens. The distal talon is well developed looking the half lophid comprising two or three small conules at the distal end of the molars. The interlophid valleys are fairly wide and deep, but narrower than in Stegolophodon stegodontoides. The cement found at the bottom of the interlophid valleys. The enamel is thick and spindle shaped enamel loop on the wear surface. The posterior face of the enamel loop is shallow concave and nearly straight on the wear surface (YUDG-Sbw 022, 008, Figure 4(a), Figure 4(b)).

\section{Discussion}

The described specimens here are identified as Stegolophodon on the basis of brachyodonty morphology, distinct median sulcus and the present of central conules on the mesial lophids. These are distinct from the lower molars of Stegolophodon latidens (Clift) and Stegolophodon stegodontoides (Pilgrim) by the increased number of lophids ( $7 \mathrm{x}$ ) which is not belonged to the latter species. These are also distinct from the $S$. cf. latidens [1] in Mae Moh, and $\mathcal{S}$. nasaiensis [12] in Na Sai, Northern Thailand by its increased lophid number (x $7 \mathrm{x}$ ) and reduced central conules in the distal lophids. Moreover the described molars share the characteristics of the advanced Stegolophodon and the primitive Stegodon. Saegusa et al. (2005) [10] classified the Asian stegodontids as the six groups based on the loph(id) structures. The present materials are referable to add in the group 6 which is belonging to the intermediate forms between Late Miocene Stegolophodons and Stegodons. The specimens (YUDG-Sbw 022 and 008) are different from the $\mathrm{M}_{3}$ of "Stegodon" primitium Liu et al., 1973 (= Stegolophodon primitium, Saegusa et al., 2005, IVPP. V. 4317, Figure 4(g)) [10] from Yuanmou, Yunnan, China by their lophid number (x $7 \mathrm{x}$ ). It means the latter species is more derived than the former, Stegolophodon iravaticus. The specimens (YUDG-Sbw $022 \& 008$ ) are also closely similarly to the lower molars of Stegolophodon group 6 of [10] from the Sandpit in Tha Chang, Thailand (CCV 65, Figure 4(f)) and from Dhedari, Pakistan (BSM 1965II, Figure 4(h)) in having seven lophids, the anterior and posterior central conules are present in the mesial tow lophids. However, the latter has been undescribed yet. Compare to the Tha Chang specimen (CCV 65), the specimens (YUDG-Sbw 008 and 022) have more reduced the anterior and posterior pretrite central conules in the mesial two lophids, and the medial sulcus is shallower than the former. Again compare with the $\mathrm{M}_{3}$ of (BSM 1965II), the specimens (YUDG-Sbw 008 and 022) are more derived in the number of lohids ( $7 \mathrm{x}$ in $\mathrm{M}_{3}$ ).

In Myanmar, only Stegolophodon type species, Stegolophodon latidens (Clift) has been described from the Yenangyaung of Irrawaddy Formation by the previous authors [1] [2] [3] [4]. This species was assigned to the Lower Pliocene [2], and the Lower Pleistocene [3] [4]. However the species of Stegolophodon has not been recorded from the Irrawaddy Formation since that time because of the 
paucity of the specimens and a few vertebrate paleontologists who are interested in the fossil proboscideans in Myanmar. Recently the dentitions of Stegolophodons and stegodons were recovered from the present localities from other localities, from 2001 to date. Among these collections, two additional species of Stegolophodon, S. stegodontoides, S. cf. S. stegodontoides [13] and the newly described species here, Stegolophodon iravaticus are added in the record of the fauna of Irrawaddy Formation in Myanmar. Stegolophodon latidens is allocated to the Upper Miocene age in modern stratigraphy. Osborn (1942) [2] mentioned the equivalent of the horizon of the $S$. latidens lectotype that the Irrawaddy Formation (= Irrawaddy Series) with the Dhok Pathan Formation of Middle Siwalik Group of India which is the Upper Miocene age [14]. Stegolophodon cf. latidens was discovered from the Middle Miocene of Mae Long Formation, in Mae Moh, Northern Thailand [12], and he described that the evolutionary stage of the Japanese Middle Miocene specimens, the Mae Moh specimens, and the lectotype of $S$. latidens is the same biostratigraphic value. Moreover Stegolophodon cf. stegodontoides was collected from the Upper Miocene of Dhok Pathan Formation in Potwar Plateau of Pakistan [15]. The mandible of Stegolophodon iravaticus were found near the stratigraphic position of $S$. stegodontoides and $S$. cf. $S$. stegodontoides from the present area. The other fact that the fossil dentions of Upper Miocene suids, Propotamochoerus cf. hysudricus, and bovids, Selenoportax vexillarius were found in the present localities. Therefore the newly discovered species, Stegolophodon iravaticus is assigned to at least the uppermost of Upper Miocene age.

\section{Conclusion}

The newly discovered molars share the characteristics of the advanced Stegolophodon and the primitive Stegodon. They exhibit the distinct median sulcus, the mesoconelets which are as large as the principal cones, the anterior and posterior central conules in the mesial two lophids and the mesio-distal expansion of the mesoconelets which belong to the advanced stegodontids, and the increased number of lophids (x $7 \mathrm{x}$ ), the reduced or absence of central conules in the distal lophids, and the developed cement in the interlophid valleys which are present in the primitive stegodonts. Stegolophodon iravaticus is related to the $\mathrm{M}_{3}$ of Sand Pit in Tha Chang, Thailand and that of from Dhedari, Pakistan which are included in the Stegolophodon group 6 of Saegusa et al. (2005) [10]. The finding of Stegolophodon iravaticus of Stegolophodon stegodontoides in the present localities is assigned to the Upper Miocene age. However, it will be necessary to find more specimens as the newly discovered materials are only isolated and lower molars.

\section{Acknowledgements}

The author is grateful to Dr. Gertrud Rössner, Department of Earth and Environmental Science, Ludwig-Maximilians-University Munich, Germany, for her 
critical reading and correction, and her kind supports during studying in $\mathrm{Mu}$ nich. I would also like to thank the Bavarian State Collection for Palaeontology and Geology for their assistance. I am also indebted to the editors of the Journal of Open Journal of Geology (OJG) and anonymous reviewers, for their critical comments that greatly helped in improving the manuscript.

\section{Conflicts of Interest}

The author declares no conflicts of interest regarding the publication of this paper.

\section{References}

[1] Clift, W. (1828) On the Fossil Remains of Two New Species of Mastodon, and of Other Vertebrated Animals Found on the Left Bank of the Irrawaddi. Transactions of the Geological Society of London, 2, 369-376. https://doi.org/10.1144/transgslb.2.3.369

[2] Osborn, H.F. (1942) Proboscidea, Vol. II. The American Museum of Natural History Press, New York, 805-1675.

[3] Colbert, E.H. (1938) Fossil Mammals from Burma in the American Museum of Natural History. Bulletin of the American Museum of Natural History, 74, 255-436.

[4] Colbert, E.H. (1943) Pleistocene Vertebrates Collected in Burma by the American Southeast Asiatic Expedition. Transactions of the American Philosophical Society, New Series, 32, 395-429.

[5] Sein, C. and Sint, T.T. (2017) Dental Morphology of Stegodontidae in Myanmar. Proceeding of the First Myanmar National Conference on Earth Sciences, Monywa, 322-337.

[6] Sein, C. (2006) Miocene-Pliocene Vertebrate Fauna of Central Myanmar with Special Reference to Kyauksaungsan, Tebingan and Kyitsonbwe Areas. PhD Dissertation, Department of Geology, University of Yangon, Yangon.

[7] Bender, F. (1983) Geology of Burma. Gebrüder Borntraeger, Berlin, 293 p.

[8] Tassy, P. (1996) Dental Homologies and Nomenclature in the Proboscidea. In: Shoshani, P. and Tassy, P., Eds., The Proboscidea: Evolution and Palaeoecology of Elephants and Their Relatives, Oxford University Press, Oxford, 21-25.

[9] Saegusa, H. (1996) Stegodontidae: Evolutionary Relationships. In: Shoshani, P. and Tassy, P., Eds., The Proboscidea: Evolution and Palaeoecology of Elephants and their Relatives, Oxford University Press, Oxford, 178-190.

[10] Saegusa, H., Thasod, Y. and Ratanasthien, B. (2005) Notes on Asian Stegodontids. Quaternary International, 126-128, 31-48. https://doi.org/10.1016/j.quaint.2004.04.013

[11] Shashoni, J. and Tassy, P. (1996) The Proboscidea: Evolution and Palaeoecology of Elephants and Their Relatives. Oxford University Press, Oxford, Appendix B, 352-353.

[12] Tassy, P., Anupandhanant, P., Ginsburg, L., Mein, P., Ratanasthien, B. and Suteethorn, V. (1992) A New Stegolophodon (Proboscidea, Mammalia) from the Early Miocene of Northern Thailand. Géobios, 25, 511-523. https://doi.org/10.1016/S0016-6995(92)80079-S

[13] Sein, C., Van der Made, J. and Rössner, G.E. (2009) New Material of Propotamo- 
choerus (Suidae, Mammalia) from the Irrawaddy Formation, Myanmar. Neues Jahrbuch für Geologie und Paläontologie Abhandlungen, 251, 17-31.

https://doi.org/10.1127/0077-7749/2009/0251-0017

[14] Barry, J.C., Morgan, M.E., Flynn, L.J., Pilbeam, D., Behrensmeyer, A.K., Raza, S.M., Khan, I.A., Badgley, C., Hicks, J. and Kelley, J. (2002) Faunal and Environmental Change in the Late Miocene Siwaliks of Northern Pakistan. Paleobiology Memoris (Memoir 3), 28, 1-71.

https://doi.org/10.1666/0094-8373(2002)28[1:FAECIT]2.0.CO;2

[15] Tassy, P. (1983). Les Elephantoidea Miocènes du Plateau du Potwar, Groupe de Siwalik, Pakistan. III. Partie: Stégodontidès, Elephantoides Indéterminés. Restes Postcrâniens Conclusions. Annales de Paléontologie (Vert.-Invert.), 69, 317-354. 